\title{
PHYSIOLOGICAL EFFECT OF ARGININE AND PUTRESCINE ON GROWTH, YIELD AND SOME CHEMICAL CONSTITUENTS OF FABA BEAN (Vicia faba L.) GROWN IN NEWLY RECLAIMED SANDY SOIL. \\ Hozayn, M. ${ }^{1}$; Mona G. Dawood ${ }^{2}$ and Mervat Sh. Sadak ${ }^{2}$ 1- Field Crop Research Department, National Research Centre, Giza, Egypt. \\ 2- Botany Department, National Research Centre, Giza, Egypt.
}

\begin{abstract}
Field trials were conducted during two successive seasons of 2005/06 and 2006/07 at the Agricultural Production and Research Station, National Research Centre, El Nubaria Province, El Behaira Governorate, Egypt. The trials aimed to study the effect of arginine and putrescine as soaking $(0.1 \& 0.2 \mathrm{mM})$ and spraying $(10 \& 20$ $\mathrm{mM}$ ) treatments on faba bean grown in newly reclaimed sandy soil. The results indicated that, all applied treatments were effective in improving growth parameters; photosynthetic pigments and carbohydrate contents of faba bean shoot. Moreover, significant increase in yield and yield components were reported due to the treatments and the most promising treatment was soaking with $0.1 \mathrm{mM}$ arginine. Chemical constituents of faba bean seeds i.e., total carbohydrates; polysaccharides; free amino acids; total soluble-N; protein and vicine contents were also increased. This study shows that putrescine and its precursor (arginine) treatments could effectively increase photosynthetic pigments, total carbohydrates and protein content of faba bean as well as yield and yield components. Thus faba bean quality and quantity could improve in such low fertility soils. Moreover, the increase in vicine content could play an important role in protecting the yielded seeds against seed pests.

Keywords: Faba bean - arginine - putrescine - yield - chemical constituents sandy soil.

\section{INTRODUCTION}

Faba bean (Vicia faba L.) is considered one of the most important feeding crops in Egypt with high yield capacity and high protein content. It contains most of the necessary amino acids for human and animal nutrition.

Polyamines are ubiquitous bioactive low molecular weight, aliphatic nitrogenous polycations that contain two or more amine groups. They are found in virtually all organisms including microorganisms, plants and animals (Evans and Malmberg, 1989). Among the most abundant and physiologically active polyamines in plants is the diamine putrescine. In plant cells polyamines frequently occur free or conjugated with phenolic compounds such as hydroxycinnamic acid, coumaric acid or caffeic acid (Bouchereau et al., 1999). Polyamines are usually produced by the decarboxylation of amino acids. In polyamine biosynthesis, arginine form putrescine via arginine decarboxylase. Arginine is used as a precursor to putrescine and other polyamines. Polyamines are essential cell components for growth and development process in higher plants as a new class of growth substances or hormonal second messenger (Glaston and Kaur-Sawhney, 1995; Tang et al., 2004; Abd El-Monem, 2007).
\end{abstract}


Hozayn, M. et al.

Exogenous application of polyamines improved growth of wheat cultivars (tillers number, leaves number, leaves area/plant and fresh \& dry weights of shoots (El - Bassiouny \& Bekheta, 2001). Also, Gupta et al. (2003) and El- Bassiouny (2004) revealed that polyamines application increased flowering, fruit setting and yield of wheat and bean plants.

Concerning the role of arginine, Davies (1997) on Phaseolus vulgaris and Nassar et al. (2003) on bean plants found that, addition of arginine induced significant increase in the growth of plant.

Abd El - Monem (2007) concluded that, the different treatments of arginine and putrescine effectively increased growth, yield and yield attributes and chemical contents of yielded grains (carbohydrate and protein) over those of the untreated control.

The aim of this work was to study the effect of soaking and spraying treatments with arginine and putrescine on the growth, yield and some chemical constituents of faba bean plants cultivated in newly reclaimed sandy soil.

\section{MATERIALS AND METHODS}

The present study was carried out at the Agricultural Production and Research Station, National Research Centre, El Nubaria Province, El Behaira Governorate, Egypt during two successive seasons of 2005/06 and 2006/07.

The physical and chemical analysis of the experimental field include the following characters: sand $93.70 \%$; silt $3.90 \%$; clay $3.40 \%$; pH 7.80 ; organic matter $0.21 \%$; $\mathrm{CaCo}_{3} 1.00 \%$; E.C. $0.50 \mathrm{mmllos} / \mathrm{cm}^{3}$ and the available total N,P,K were $9.20,3.60,23.50 \mathrm{ppm}$, respectively at $0-60 \mathrm{~cm}$ depth as described by Chapman and Pratt (1978).

The soil was ploughed twice, ridged and divided into plots during seed preparation. $150 \mathrm{~kg}$ calcium superphosphate/fed. $\left(15.5 \% \mathrm{P}_{2} \mathrm{O}_{5}\right)$ was added as a general application.

The experiment includes the following treatments:

T1. Control 1 (soaking seeds for 12 hours in water)

T2. Soaking seeds for 12 hours in $0.1 \mathrm{mM}$ arginine.

T3. Soaking seeds for 12 hours in $0.2 \mathrm{mM}$ arginine.

T4. Soaking seeds for 12 hours in $0.1 \mathrm{mM}$ putrescine.

T5. Soaking seeds for 12 hours in $0.2 \mathrm{mM}$ putrescine.

T6. Control 2 (spraying plants with water at 45 and 60 days from sowing (DAS)).

T7. Spraying plants with $10 \mathrm{mM}$ arginine at 45 and 60 DAS.

T8. Spraying plants with $20 \mathrm{mM}$ arginine at 45 and 60 DAS.

T9. Spraying plants with $10 \mathrm{mM}$ putrescine at 45 and 60 DAS.

T10. Spraying plants with $20 \mathrm{mM}$ putrescine at 45 and 60 DAS.

The treatments were arranged in Completely Randomized Block Design (CRBD) with four replicates. The experimental unit consisted of 6 ridges $60 \mathrm{~cm}$ apart and 3 meters a long $\left(10.80 \mathrm{~m}^{2}\right)$. Faba bean seeds (cv. 
Masr 1) were sown in hill spaced $20 \mathrm{~cm}$ apart at both sides of ridge on November $10^{\text {th }}$ and $15^{\text {th }}$ in the first and second seasons, respectively. After 15 days from sowing faba bean plants were thinned at two plants per hill. Nitrogen fertilizer as ammonium sulphate $(20.6 \% \mathrm{~N})$ was added at the level of $60 \mathrm{~kg} \mathrm{~N} / \mathrm{fed}$ in two equal doses at 15 and 30 days from sowing. Also, $100 \mathrm{~kg}$ potassium sulphate/fed. $\left(48 \% \mathrm{~K}_{2} \mathrm{O}\right)$ was added at 35 days after sowing. Sprinkler irrigation was applied as followed in the districted. Faba bean plants were manually harvested on April $10^{\text {th }}$ and $15^{\text {th }}$ in the first and second seasons, respectively.

After 75 days from sowing, five plants were randomly taken from each plot to determine plant height. Dry weight of plant $(\mathrm{g})$ was determined after oven drying at $70^{\circ} \mathrm{C}$ till constant weight.

At harvest, a random sample of ten plants were taken from each plot to determine plant height $(\mathrm{cm})$, number of branches and pods/plant, weight of pods and seeds/plant (g), number of seeds/pod and 100-seed weight $(\mathrm{g})$. Plants from the middle three ridges after excluding $0.5 \mathrm{~m}$ at both sides in each plot $\left(3.60 \mathrm{~m}^{2}\right)$ were harvested and their pods were air dried and threshed to estimate seed yield $(\mathrm{kg} / \mathrm{fed})$.

Chemical analysis:

Photosynthetic Pigments (chlorophyll a, chlorophyll b and carotenoids) of leaves at 75 days from sowing were determined spectrophotometrically as the method described by Moran (1982). Total soluble carbohydrates were determined using modifications of the procedures of Yemm and Willis, (1954). Total carbohydrate contents were determined according to Dubois et al., (1956). Polysaccharides were calculated by the difference between total carbohydrates and soluble carbohydrates. Protein content in the seeds was determined by using micro-kjeldahl method as described in A.O.A.C. (1990). Soluble $-\mathrm{N}$ was estimated according to the procedure reported by Pirie (1955). Free amino acids were determined as the method described by Muting and Kaiser (1963). Vicine content was determined according to the method described by Collier (1976).

\section{Statistical analysis:}

The obtained results were subjected to the statistical analysis by $M$ STAT-C statistical analysis program (MSTAT, 1988). Since the trend was similar in both seasons, Bartlett's test (1937) and the combined analysis of the two growing seasons were applied. Means were compared using least significant difference test at 5\% probability level (Snedecor and Cochran 1989),

\section{RESULTS AND DISCUSION}

\section{Growth parameters:}

Data presented in (Fig. 1) show that the growth parameters (plant height and dry weight/plant) of faba bean plants increased either by soaking or spraying with arginine or putrescine at different concentrations as compared with control. The results show that soaking faba bean seeds in either arginine $(0.1 \& 0.2 \mathrm{mM})$ or putrescine $(0.1 \mathrm{mM})$ was more effective in 
increasing growth parameters than foliar spraying treatments with 10 and 20 $\mathrm{mM}$ of both substances. Soaking treatment with arginine or putrescine at lower concentration $(0.1 \mathrm{mM})$ induced greater efficiency than higher concentration $(0.2 \mathrm{mM})$. Foliar spraying with arginine or putrescine at higher concentration $(20 \mathrm{mM})$ was more effective than lower concentration $(10 \mathrm{mM})$. The most promising treatment was soaking seeds with $0.1 \mathrm{mM}$ arginine, while, optimum concentration in foliar treatment was $20 \mathrm{mM}$ arginine. The obtained results are in agreement with those of Nassar et al. (2003) and Abd ElMonem (2007) who mentioned that arginine or putrescine induced significant increases in the growth parameters of bean and wheat plants, respectively and attributed such improvement to the increase in growth rate due to high levels of endogenous IAA, GAs and cytokinins in the treated plants.

Moreover, the increase in the dry weight of treated faba bean plant is a reflection to the increase in cell division (Mader and Hanke, 1997 on soybean) and/or cell enlargement and differentiation (Glastone and KaurSawhney, 1995 on pea plants). Also, Davies (1995) reported that, polyamines are currently considered to be regulators of plant growth and differentiation.

\section{Photosynthetic pigments:}

Significant increases in photosynthetic pigments due to arginine and putrescine treatments (soaking and spraying) were recorded in (Fig. 1). Soaking faba bean seeds with $0.10 \mathrm{mM}$ arginine as well as foliar spraying with $20 \mathrm{mM}$ arginine induced the highest significant increase in chlorophyll (a), chlorophyll (b), total chlorophyll $(a+b)$, carotenoids and total pigments content as compared with control plant or other treatments. Similar results of the promoting effects of polyamines on photosynthetic pigments had been observed by Das et al. (2002) on Morus alba and El-Bassiouny (2004) on pea. The role of polyamines and their precursor arginine in chlorophyll synthesis is reported by Askar and Treptow (1986) who showed a positive correlation of polyamines on the enhancement of photosynthetic pigments and different growth parameters. In this connection, Chattopadhayay et al. (2002) concluded that polyamines prevented chlorophyll losses of rice seedlings through inhibition of photochemical reactions of photosynthesis.

\section{Carbohydrate contents of shoot:}

Fig. (1) shows that arginine or putrescine treatments induced marked increases in total carbohydrate and polysaccharide contents accompanied by a significant decrease in total soluble carbohydrates of faba bean shoot. The maximum increase in total carbohydrates and in polysaccharides concomitant with minimum decrease in total soluble carbohydrates resulted from soaking seeds with $0.1 \mathrm{mM}$ arginine. These increments were closely correlated to stimulation of chlorophyll biosynthesis and consequently the greater metabolites. These results are in agreement with those reported by ElBassiouny and Bekheta (2001) and Abd El Monem (2007) on wheat. 

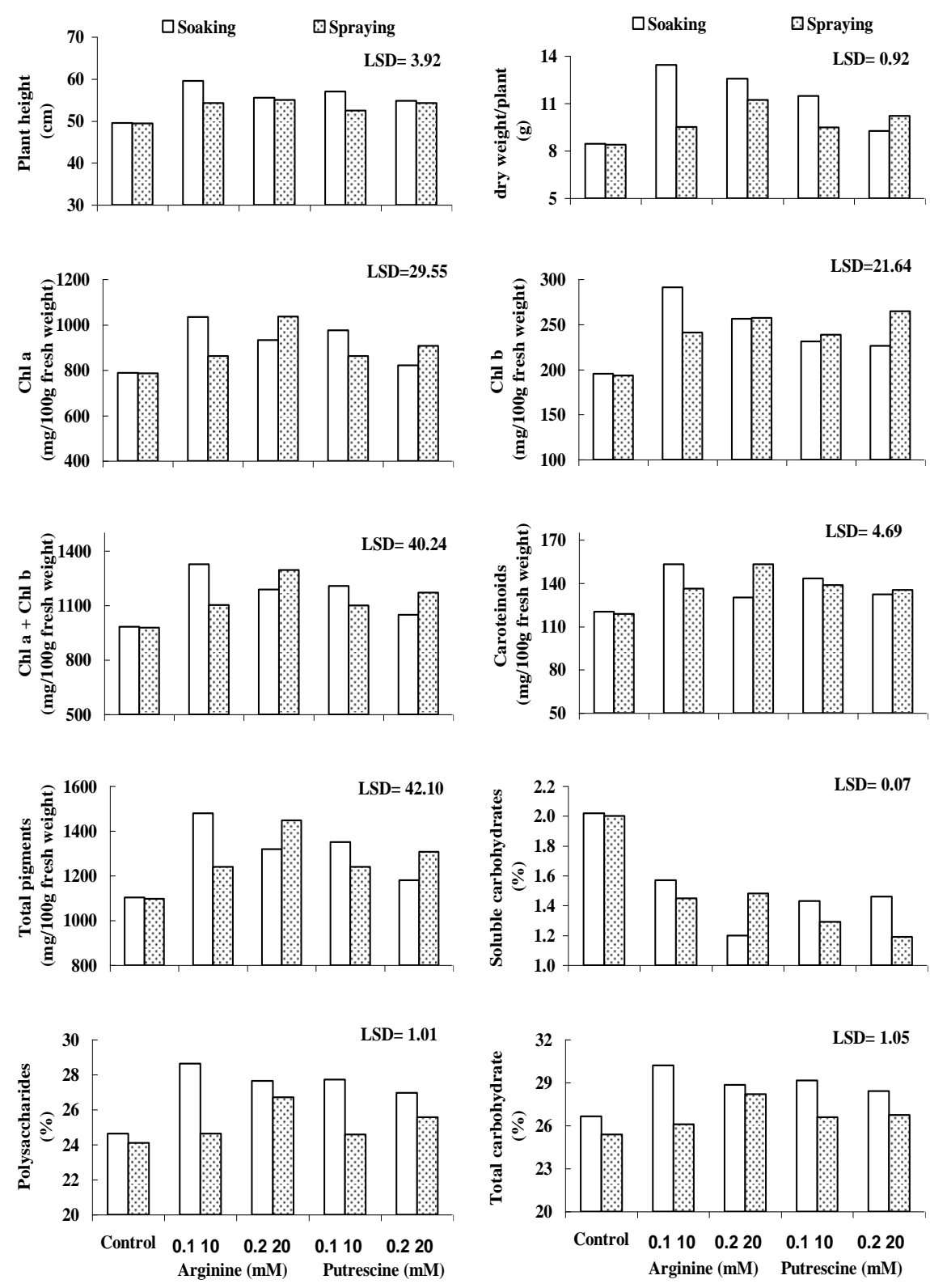

Fig. (1): Effect of arginine and putrescine on growth parameters and chemical contents of faba bean plants at 75 days from sowing (combined data over two seasons). 
Yield and yield attributes:

The results presented in Table (1) show that all treatments caused significant increase in plant height, number of branches and pods per plant; pods and seeds weight per plant; seed index (100-seed weight); number of seeds per pod and seed yield (ardab/fed) of faba bean plants. Soaking treatment with $0.1 \mathrm{mM}$ arginine gives the highest value in all prementioned yield parameters. The positive increase in the yield and its components in response to arginine or putrescine are in agreement with those obtained by lqbal and Ashraf (2005) and Abd-El-Monem (2007) on wheat plants. Moreover, El-Bassiouny (2004) reported that, the increase in yield of pea over the control in response to putrescine treatment resulted from the increase in number of flowers per plant which led to an increase the number of fruits, increase in the number of seeds produced per fruit as well as increase of their fresh and dry weight. Polyamine treatment appeared likely to cause an increase in the accumulation of photosynthetic assimilates which cause an increase in seed filling.

\section{Chemical analysis of faba bean seeds:}

Fig.(2) shows that soaking treatments with arginine or putrescine $(0.1$ and $0.2 \mathrm{mM}$ ) and spraying treatments with 10 and $20 \mathrm{mM}$ arginine or putrescine significantly increased polysaccharide contents of faba bean seeds. Whereas, soaking treatments significantly increased total carbohydrate over the untreated plant. It is evident that, soluble carbohydrates decreased significantly in response to all applied treatments. Abd El Moneam (2007) found that the external supply of putrescine or arginine increased the carbohydrate contents of wheat grains.

The applied treatments increased free amino acids of the faba bean seeds as compared to control treatment (Fig. 2). Soaking treatments induced marked increases in free amino acids than those of spraying. The highest value was recorded from soaking seeds with $0.1 \mathrm{mM}$ arginine and $0.2 \mathrm{mM}$ putrescine.

Fig. (2) shows that all applied treatments induced significant increases in soluble- $\mathrm{N}$ and protein contents of the yielded seeds as compared to control. The maximum increase in protein contents $(21.73$ and $15.96 \%)$ and in soluble-N (42.65 and $42.29 \%)$ due to soaking treatments with arginine or putrescine at $0.1 \mathrm{mM}$, respectively over the control. In this respect, El-Bassiouny (2004); Bekheta and El-Bassiouny (2005); Talaat et al., (2005) stated that putrescine treatments significantly increased the protein \% of the pea seeds, wheat grains and periwinkle transplants, respectively. This increase may be attributed to either the translocation of amino acids from shoots to seeds and increasing protein synthesis. Moreover, Sood and Nagar (2003) mentioned that polyamines act as activator to RNA, protein and/or inhibit certain proteolytic enzymes. Vervaeke et al. (2005) stated that arginine was probably related to protein synthesis in Aechmea fasciata plant.

The increase of protein and carbohydrate contents of the faba bean seeds to different applied treatments could be attributed to the role of polyamines in increasing photo-assimilates and subsequently the growth rate of faba bean plants. 
J. Agric. Sci. Mansoura Univ., 33 (3), March, 2008

$\mathrm{t}$ 
Hozayn, M. et al.
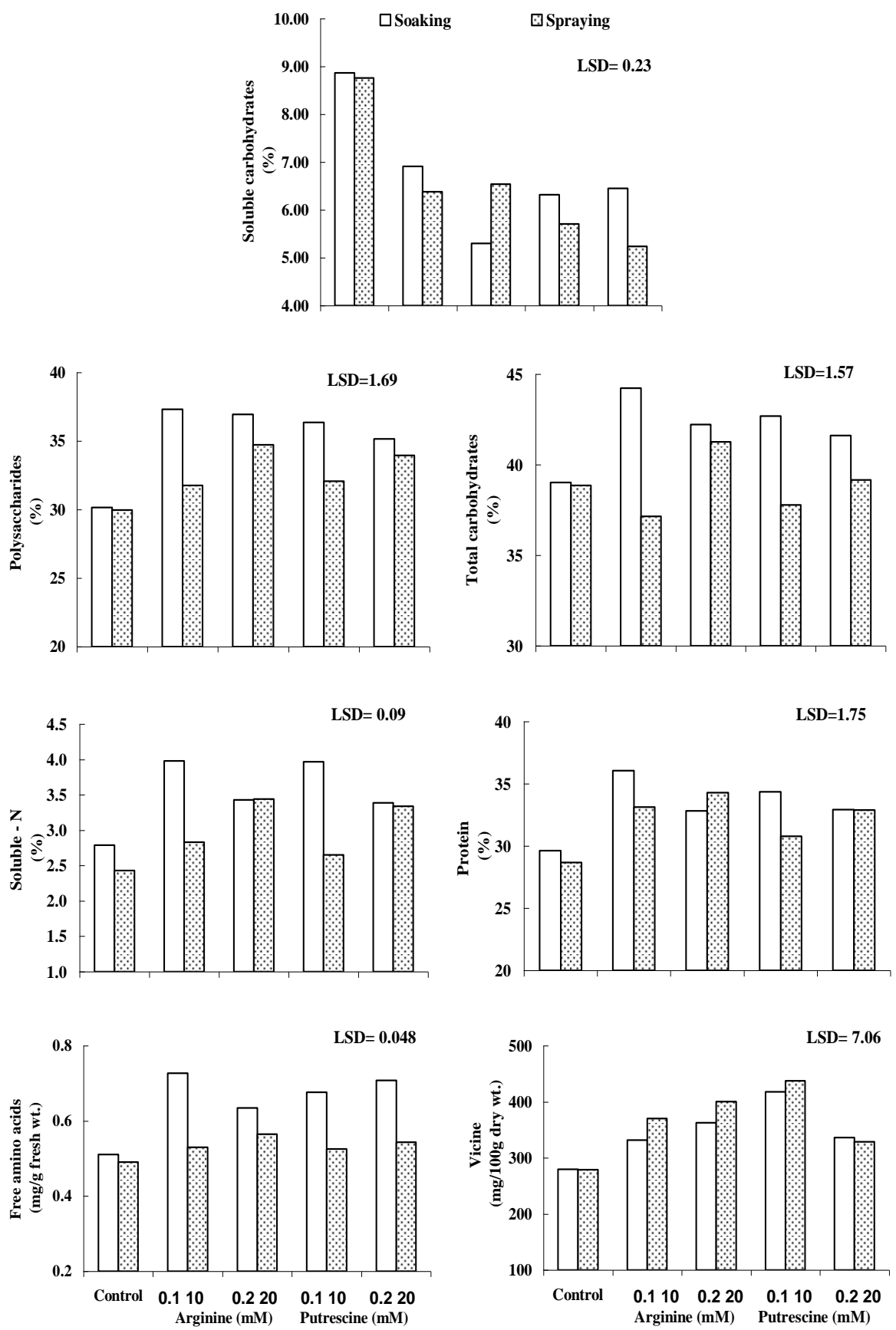

Fig. (2): Effect of arginine and putrescine on seed quality of faba bean plants (combined $\mathrm{t}$ data over two seasons). 
All treatments caused significant increase in vicine content (pyrimidone glucopyranosides) of the faba bean seeds (Fig. 2). The maximum increase attained was $56.85 \%$ when spraying of faba bean plants with $10 \mathrm{mM}$ putrescine and the minimum increase $(17.85 \%)$ was resulted from spraying putrescine with higher concentration. The increase in vicine resulted from spraying or soaking treatments with arginine concomitant with increase in arginine concentration and vice versa in case of putrescine. Both environmentally and genetic factors seems to affect the concentrations of favism causative agents (vicine and convicine) in the seeds of Vicia faba plants. The increase in vicine contents ( $\mathrm{N}$ - rich compounds) may be attributed to the effect of these treatments on metabolic pathway of vicine precursor (orotic acid) formation which is responsible for the formation of pyrimidine ring of these constituents. Such concentrations could be expected to provide better protection from the pests of seeds, most of which begin their life cycle early in the development of the seed (Ramsay and Griffiths, 1996).

\section{CONCLUSION}

It could be concluded from this study that the effect of putrescine or its precursor arginine could increases the photosynthetic pigments of faba bean leaves and could affect other components like, total carbohydrates and protein contents of the seeds as well as yield components. This may be attributed to the increase in the efficiency of solar energy conversion which maximized the growth ability of plant and consequently increased its productivity and yield components.

\section{REFERENCES}

Abd El-Monem, A. A. (2007): Polyamines as modulators of wheat growth, metabolism and reproductive development under high temperature stress. Ph.D. Thesis, Ain Shams Univ., Cairo, Egypt.

A.O.A.C. (1990): Official methods of analysis. 20 th ed. Association of Official Analytical Chemists. Arlington, Virginia, U.S.A.

Askar, A. and H. Treptow (1986): Biogene amine in lebensmittlen a Veleg Eugen ulmer, Stuttgart.

Bartlett, M. S. (1937). Properties of sufficiency and statistical tests. Proceedings of the Royal Statistical Society Series A 160, 268-282.

Bekheta, M.A. and H.M.S. El-Bassiouny (2005): Response of two wheat cultivars grown under salinity stress to putrescine treatment. J. Agric. Sci. Mansoura Univ., 30 (8): 4505-4521.

Bouchereau A., Aziz A., Larher F. and Murting- Tanguy J. (1999): Polyamines and development challenges recent development. Plant Sci., 140: 103-125.

Chapman, H.O. and P.E. Pratt (1978): Methods of Analysis for Soils, Plants and Water. Univ. of California Agric. Sci. Priced Publication. 4034. P.50.

Chattopadhayay, M.K.; B.S. Tiwari.; G.Chattopadhyay; D. N. Anindica Bose Sengupta; G.Bharati; G.Chattopadhyay; A.Bose, and B.Gosh (2002): Protective role of exogenous polyamines on salinity stressed rice (Oryza sativa) plants. Physiol. Plant. 116: 192 - 199. 
Collier, H.B. (1976): The estimation of vicine in faba beans by an ultraviolet spectrophotometric method. J.Inst.Can.Sci. Technol. Aliment 9,155159.

Das, C.; T. Sengupta; S. Chattopadhyay; M. Setua; N.K. Das and B. Saratchandra, (2002): Involvement of kinetin and spermidine in controlling salinity stress in mulberry (Morus alba L. cv. S1). Acta. Physiol. Planta. 24 (1): $53-57$.

Davis, D.G. (1995): Plant hormones: Physiology and biochemistry and biology. P.159 Kluwer Academic Publishers, London.

Davis D. G. (1997): Polyamines, auxins and organogenesis in leafy spurge (Euphorbia esula L.) J. Plant Physiol. 151: 603 - 609.

Dubois, M., K.A. Gilles; J.K. Hamilton and P.A. Robers (1956): Colorimetric method for determination of sugars and related substances. Ann. Chem. 28: $350-356$.

El-Bassiouny, H.M.S. (2004): Increasing thermotolerance of Pisum sativum L. plants through application of putrescine and stigmasterol. Egypt. J. Biotech. 18: 93-118.

El- Bassiouny, H.M.S. and M. A.Bekheta (2001): Role of putrescine on growth, regulation of stomatal aperture, ionic contents and yield by two wheat cultivars under salinity stress. Egyptian J. Physiol. Sci, 2-3: 235258.

Evans, P. T. and Malmberg, R. L. (1989): Do polyamines have a role in plant development? Ann. Rev. Plant Physiol. Plant Mol. Biol. 40: 235 - 269.

Glaston, A.W. and R. Kaur-Sawhney. (1995): Polyamines as endogenous growth regulators- In Plant Hormones: Physiology, Biochemistry and Molecular Biology. 2nd Ed. (P.J. Davis, ed), pp. 158- 178. Kluwer Academic Publishers, Dordrecht ISBNO.

Gupta S., Sharma M. L., Gupta N. K. and Kumar A. (2003): Productivity enhancement by putrescine in wheat (Triticum aestivum L.). Physiol. Mol. Biol. Plants, 9: (2) $279-282$.

lqbal, M. and M.Ashraf (2005): Changes in growth, photosynthesis capacity and ionic relations in spring wheat (Triticum aestivum L.) due to presowing seed treatment with polyamines.Plant Growth Regul.46:19-30.

Mader, J.C. and D.E. Hanke (1997): Polyamine sparing may be involved in the prolongation of cell division due to inhibition of phenylpropanoid synthesis in cytokinin - starved soybean cells. J. Plant Growth Regul. 16: $89-93$.

MSTAT-C (1988): MSTAT-C, a microcomputer program for the design, arrangement and analysis of agronomic research. Michigan State University, East Lansing.

Moran, R. (1982): Formulae for determination of chlorophyllous pigments extracted with N, N- dimethylformamide. Plant Physiol. 69:1371-1381.

Muting, D. and E. Kaiser (1963): Spectrophotometric method of determining of amino- $\mathrm{N}$ in biological materials by means of the ninhydrin reaction. Seyler"s Zschr. Physiol. Chem. 332-276. 
Nassar, A.H.; K.A. El-Tarabily and K. Sivasithamparam (2003): Growth promotion of bean (Phaseolus vulgaris L.) by a polyamine - producing isolate of Streptomyces griseoluteus. Plant Growth Regul. 40 (2): 97 106.

Pirie, F.G. (1955): Proteins. In Modern Methods of Plant Analysis. Edited by (Peach, K. and M.V. Tracey,). IV: 23-68 Springer Verlag, Berlin.

Ramsay, G. and W. Griffiths (1996): Accumulation of vicine and convicine in Vicia faba and V.narbonensis. Phytochem. 42(1):63-97.

Snedecor, George W. and Cochran, William G. (1989), Statistical Methods, Eighth Edition, lowa State University Press.

Sood, S. and P. K, Nagar (2003): The effect of polyamines on leaf senescence in two diverse rose species. Plant Growth Regul. 39 ( 2): $155-160$.

Talaat, I. M., Bekheta, M. A. and Mahgoub, M. H. (2005): Physiological response of periwinkle plants Catharanthus roseus $\mathrm{L}$. to tryptophan and putrescine. Int. J. Agric. Biol., 7(2): 210-213.

Tang, W.; R.J. Newton and V. Outhavong (2004): Exogenously added polyamines recover browning tissues into normal callus cultivars and improve plant regeneration in pine. Physiol. Plant., 122 (3): 386-395.

Vervaeke, I.; L. Sitichelbout; E. Londers; R. Deroose and M.P. De Proft (2005): Influence of arginine, ornithine, DFMO and polyamines on division of the generative nucleus in cultured pollen tubes of Aechmea fasciata (Bromeliaceae). Plant Cell Tiss. Organ. Cult. 81: 77-82.

Yemm, E. W. and A. J. Willis, (1954): The respiration of barley plants.IX. The metabolism of roots during assimilation of nitrogen. New Phytol. 55: $229-234$.

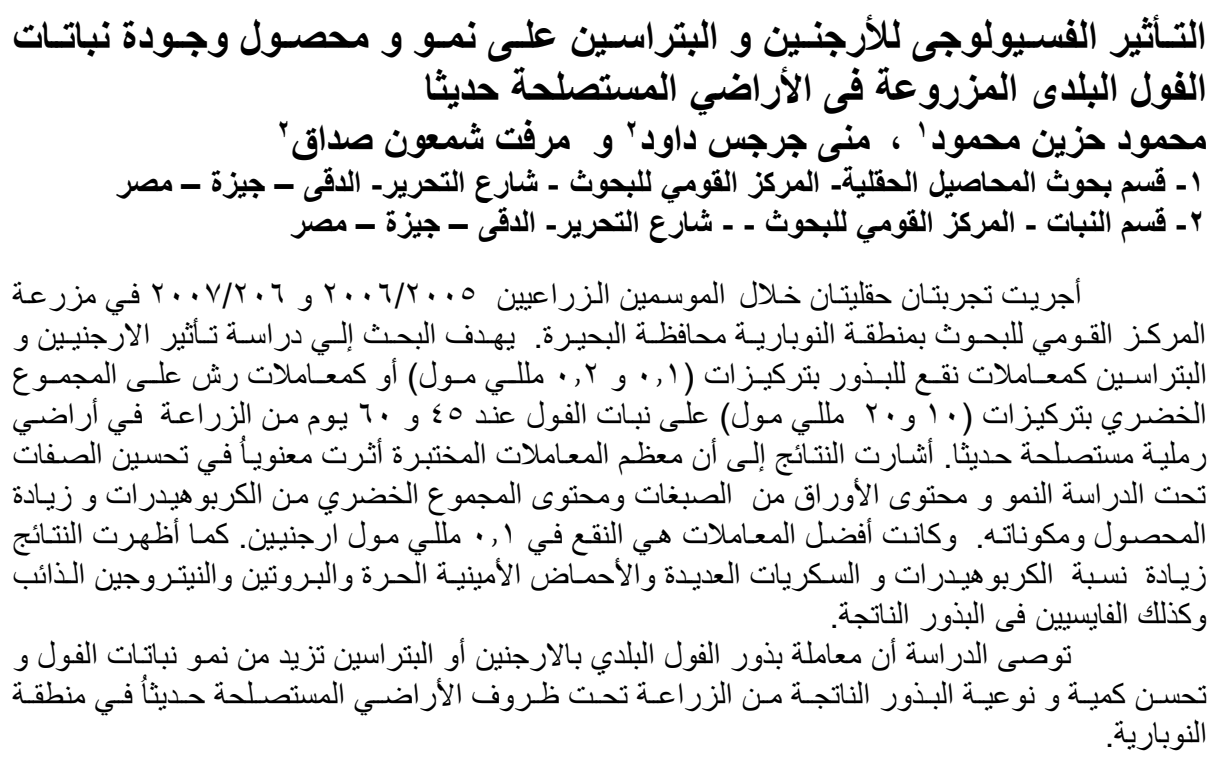


Table (1): Effect of arginine and putrescine on yield and yield components of faba bean plants (combined data over two seasons).

\begin{tabular}{|c|c|c|c|c|c|c|c|c|}
\hline \multirow[b]{2}{*}{ Treatments } & \multirow{2}{*}{$\begin{array}{l}\text { Plant ht. at } \\
\text { harvest } \\
\text { (cm) }\end{array}$} & \multicolumn{2}{|c|}{\begin{tabular}{|c|}
$\begin{array}{c}\text { Number/ } \\
\text { plant }\end{array}$ \\
\end{tabular}} & \multirow{2}{*}{$\begin{array}{l}\text { No. of } \\
\text { seeds/ } \\
\text { pod }\end{array}$} & \multicolumn{2}{|c|}{$\begin{array}{l}\text { Weight } \\
\text { (g/plant) }\end{array}$} & \multirow{2}{*}{$\begin{array}{c}\text { 100-seed } \\
\text { weight } \\
\text { (g) }\end{array}$} & \multirow{2}{*}{$\begin{array}{c}\text { Seed } \\
\text { yield } \\
\text { (ardab/fed) }\end{array}$} \\
\hline & & Branches & Pods & & Pods & Seeds & & \\
\hline${ }^{*}$ T1. Control 1(soaking seeds in water) & 70.25 & 1.52 & 10.27 & 2.75 & 21.54 & 16.45 & 74.62 & 13.18 \\
\hline Soaking seeds in $0.1 \mathrm{mM}$ arginine. & 79.50 & 3.75 & 13.25 & 3.75 & 31.86 & 25.01 & 83.31 & 15.77 \\
\hline Soaking seeds in $0.2 \mathrm{mM}$ arginine. & 76.00 & 3.00 & 12.75 & 3.51 & 29.48 & 24.23 & 79.07 & 15.37 \\
\hline Soaking seeds in $0.1 \mathrm{mM}$ putrescine. & 77.55 & 3.50 & 12.51 & 3.62 & 30.78 & 23.44 & 81.22 & 15.05 \\
\hline T5. Soaking seeds in $0.2 \mathrm{mM}$ putrescine. & 75.71 & 2.51 & 11.12 & 3.37 & 26.29 & 20.82 & 78.67 & 14.43 \\
\hline${ }^{* \star}$ T6. Control 2 (spraying plants with water) & 70.19 & 1.49 & 10.25 & 2.74 & 21.49 & 16.40 & 74.48 & 13.16 \\
\hline T7. Spraying plants with $10 \mathrm{mM}$ arginine. & 74.25 & 2.53 & 11.13 & 3.01 & 25.31 & 22.21 & 80.07 & 15.05 \\
\hline Spraying plants with $20 \mathrm{mM}$ arginine. & 76.50 & 3.37 & 12.26 & 3.02 & 28.35 & 24.02 & 82.67 & 15.60 \\
\hline T9. Spraying plants with $10 \mathrm{mM}$ putrescine. & 73.75 & 2.11 & 11.01 & 3.02 & 23.86 & 20.82 & 79.43 & 14.73 \\
\hline T10. Spraying plants with $20 \mathrm{mM}$ putrescine. & 75.51 & 2.66 & 11.75 & 3.01 & 27.66 & 23.58 & 80.07 & 15.45 \\
\hline LSD at $5 \%$ & 3.16 & 0.61 & 1.18 & 0.63 & 1.18 & 1.64 & 1.01 & 0.66 \\
\hline
\end{tabular}

soaked for 12 hours

**T6-T10: Plants sprayed at 45 and 60 days from sowing. 